\title{
VEGFA Gene Product
}

National Cancer Institute

\section{Source}

National Cancer Institute. VEGFA Gene Product. NCI Thesaurus. Code C126412.

A protein encoded by the VEGFA gene. 